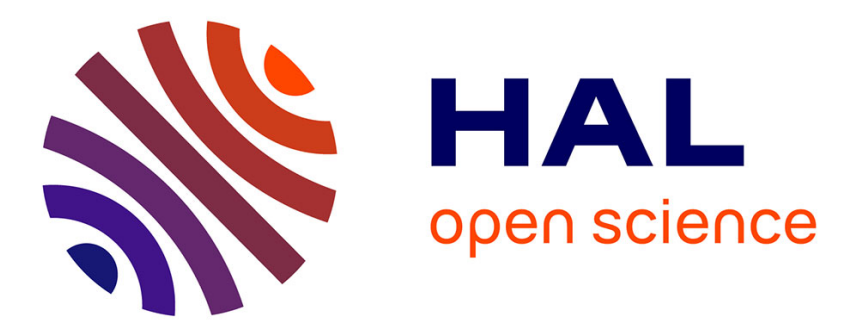

\title{
Large dams and uncertainties. The case of the Senegal River (West Africa)
}

Dominique Dumas, Michel Mietton, O. Hamerlynck, F. Pesneaud, A. Kane, A. Coly, S. Duvail, M. L. O. Baba

\section{- To cite this version:}

Dominique Dumas, Michel Mietton, O. Hamerlynck, F. Pesneaud, A. Kane, et al.. Large dams and uncertainties. The case of the Senegal River (West Africa). Society \& Natural Resources, 2010, 23 (11), pp.1108-1122. 10.1080/08941920903278137 . halshs-00363620

\section{HAL Id: halshs-00363620 \\ https://shs.hal.science/halshs-00363620}

Submitted on 27 Apr 2012

HAL is a multi-disciplinary open access archive for the deposit and dissemination of scientific research documents, whether they are published or not. The documents may come from teaching and research institutions in France or abroad, or from public or private research centers.
L'archive ouverte pluridisciplinaire HAL, est destinée au dépôt et à la diffusion de documents scientifiques de niveau recherche, publiés ou non, émanant des établissements d'enseignement et de recherche français ou étrangers, des laboratoires publics ou privés. 
D. Dumas, M. Mietton, O. Hamerlynck, F. Pesneaud, A. Kane, A. Coly, S. Duvail, M. L. O. Baba, 2010. Large dams and uncertainties. The case of the Senegal River (West Africa). Society and Natural Ressources, volume 23, issue 11, 1108-1122.

\section{Large dams and uncertainties.}

\section{The case of the Senegal River (West Africa)}

D. Dumas (1), M. Mietton (2), O. Hamerlynck (3), F. Pesneaud (4), A. Kane (5), A. Coly (6), S. Duvail (7), M. L. O. $\mathrm{Baba}(8)$

1 - Université Joseph Fourier, Institut de Géographie Alpine, Grenoble, France

2 - Université Jean Moulin, Centre de Recherche en Géographie et Aménagement, Lyon, France

3 - Centre for Ecology and Hydrology, Wallingford, Crowmarsh Gifford, Oxfordshire, UK.

4 - Université Louis Pasteur, Faculté de Géographie, Strasbourg, France

5 - Université Cheik Anta Diop, Département de Géographie, Dakar, Sénégal

6 - Université Gaston Berger, Section de Géographie, Saint-Louis, Sénégal

7 - Institut Français de Recherche en Afrique, Nairobi, Kenya

8 - International Union for Conservation of Nature, Nouakchott, Mauritanie

Corresponding author

M. Dominique Dumas

Université Joseph Fourier Grenoble 1, Institut de Géographie Alpine, 14bis, avenue Marie Reynoard, 38100 Grenoble, France

e-mail: dominique.dumas@ujf-grenoble.fr 


\begin{abstract}
This paper examines the environmental and socio-economic consequences of hydraulic infrastructural changes along the Senegal River valley and estuary. During the 1980s, two dams were built along the valley floor to facilitate hydro-electrical production and regular water supply for crop irrigation. In 2003, a breach was dug across Barbary Spit to alleviate flooding in the nearby Saint-Louis city. Although these structures helped regulate the river flow, they also resulted in a series of unforeseen impacts. The study examines these, after on-site measurements (topometry, water salinity, piezometry), analysis of hydrological data, field observations, and surveys with dam managers, state regional directions and local stakeholders. It stresses the urgency of elaborating models of hydraulic management to limit the negative consequences of the hydraulic constructions. These models should consider the variety of water uses in the middle valley and delta, and also the water safety and quality (salinity) downriver from Diama Dam.
\end{abstract}

Keywords Barbary Spit, breach, dams, management, risks, salinity, uncertainties

\title{
Introduction
}

Since the late 1980s, the Senegal River valley, located in Mali, Senegal and Mauritania has progressively become more artificially engineered with the building of embankments, free-flow canals, irrigation ditches and sluicegates. These hydraulic structures were developed in direct connection with the construction of two larger structures, the Manantali dam, located upriver in Mali, and the Diama dam, located near the mouth of the river in Senegal (see Fig.1). The two dams originally had clearly distinct, but complementary roles. The Diama dam was primarily designed to block sea water intrusion within the valley and has a limited $\left(0.25 \mathrm{~km}^{3}\right)$ stocking capacity. However, because of ever-increasing farming and agro-industrial demands, the dam's primary function was shifted to that of a reservoir dam. The Manantali dam, on the other hand, was designed to control river flow and has a larger hydraulic capacity of approximately $12 \mathrm{~km}^{3}$. 
Prior to the construction of the dam, the surrounding natural environment precluded sustainable development as inter-annual climatic conditions were highly variable (Michel 1973; Belloncle 1985; Boutillier and Schmitz 1987), with great disparities in rainfall, magnitude, and duration of floods. Furthermore, soils were exposed to increasing salinity as the saltwater table intruded into the delta and the saline undercurrent flowed upriver. The flat terrain and the need to build complex, costly infrastructure for flood protection, irrigation and drainage made water management difficult.

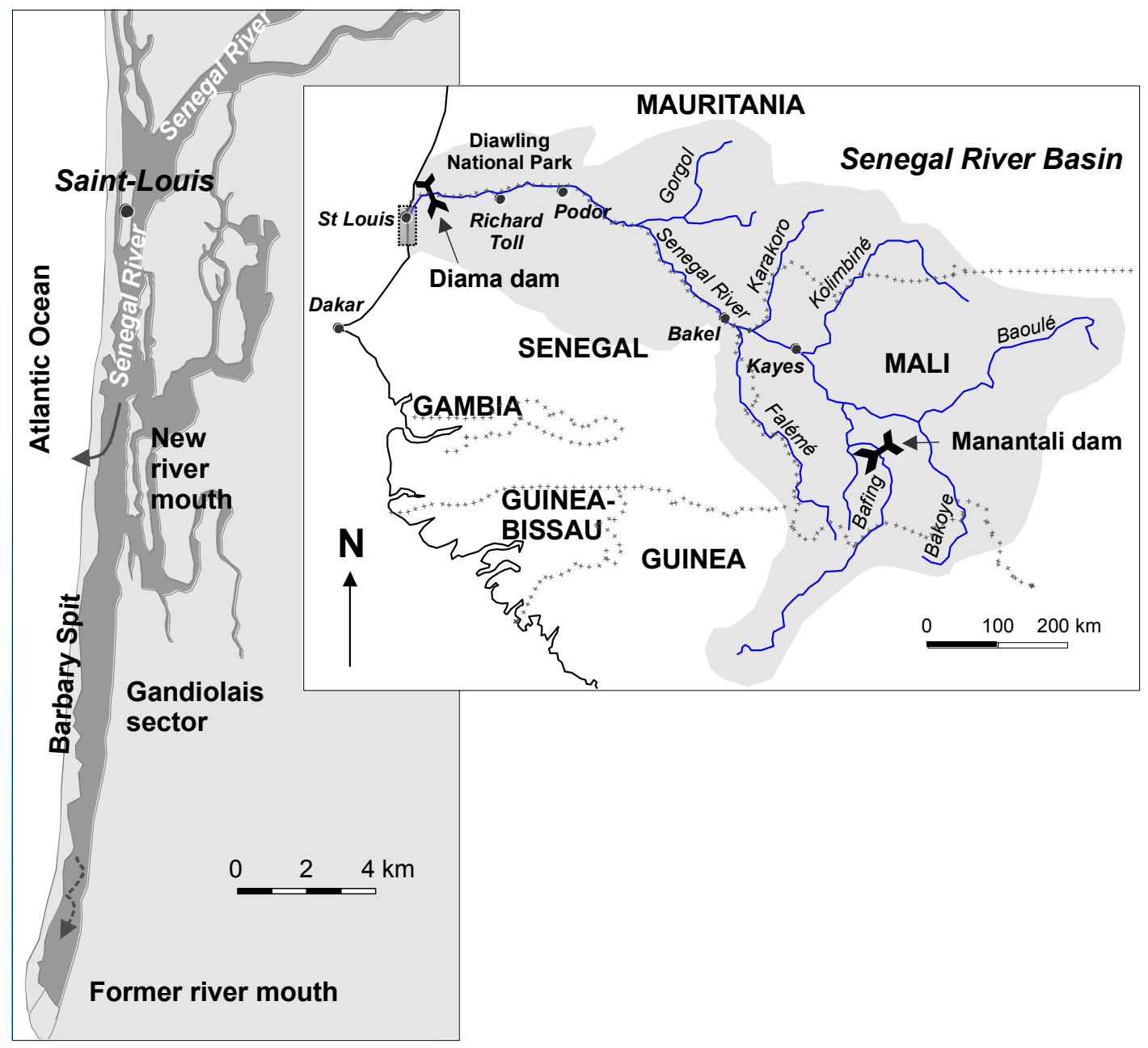

Fig. 1. The Senegal river basin and its new mouth. 
Dams and sluicegates enable regulation of the water flow of rivers, and water management depends extensively on human decisions. Here, the management priorities for the two dams were predominantly geared towards the development of irrigated crops in the former flood plains and electricity production at Manantali. Accordingly, river authorities tended to maintain high water levels in the Manantali reservoir as long as possible. This was not compatible with a management scheme aimed at controlling floods down river from Diama. Thus, because the Manantali dam can control only part of the river basin, Saint-Louis city was flooded in September 2003. This could not be prevented or controlled by the dams. Furthermore, the effects of the first flood were amplified when a second flood wave was observed upriver (at Bakel) at the same time and was expected to reach the city twenty days later. Saint-Louis is located approximately $30 \mathrm{~km}$ from the river mouth and is separated from the ocean by a long coastal spit (the Barbary Spit). In order to enable the draining of the river waters and shorten the distance between the town and the river mouth, an artificial opening in the Barbary Spit was dug as an emergency response, seven $\mathrm{km}$ down river from Saint-Louis. The result was an immediate reduction in the flood.

Control of the river discharge via the dams and embankments, and, more recently, the opening of the Barbary Breach downriver, have led to drastic changes in the river flow and abrupt modifications of the originally amphibian environment. This led to unforeseen environmental impacts, most of which appear to have arisen from the initial uncertainties regarding the midand long-term consequences of the hydraulic infrastructure and its management: the unexpected occurs and these new constraints require frequent adjustments in the water management. Such a reactive process leads to a reduced efficiency when facing extreme hydrological events. Consequently, the uncertainties and limitations imposed by the hydraulic infrastructure and the Barbary Breach impact water control managers and the local populations living in the lower part of the Delta.

Over two decades after the first water management efforts in the Senegal River valley, it is possible to appraise the consequences. We first compare the economic objectives, as proclaimed by the Office de Mise en valeur de la Vallée du Sénégal, (OMVS Senegal River Development Agency) at the time the dams were as constructed, with the observed results. Then we address the issue of the unforeseen environmental impacts brought about by the artificial transformation 
of the valley. Finally, we will show that the opening of the breach to protect Saint-Louis from the floods in 2003 was a short-term solution and that more recent complications have arisen.

\section{Conceptual Framework}

The social-ecological systems (SESs) of the Delta and along the Senegal River valley have long rested on very subtle adaptations to annual variations of rainfall and river flow/drainage. The hydraulic infrastructure, i.e., the two dams [Manantali: $11.3 \mathrm{~km}^{3}$ for a surface of $475 \mathrm{~km}^{2}$ at a water level of $208 \mathrm{~m}$; Diama, $0.25 \mathrm{~km}^{3}$ for a surface of $235 \mathrm{~km}^{2}$ at a water level of $1.5 \mathrm{~m}$ ], a number of embankments, and more recently, the artificial breaching of Barbary Spit, have greatly modified the hydrological conditions in the middle delta and estuary. This has led to a major reorganization of the SESs. The concepts of robustness and resilience are often used to describe and understand the changes in SESs integrated in highly uncertain environments (Gunderson and Holling 2002; Berkes et al. 2003; Anderies et al. 2004; Janssen et al. 2007). The notion of resilience appears particularly relevant to the framework of the present study. Resilience has been defined as a system's capacity to sustain shocks, to adapt to changes, and to persist, often at the expense of some alterations in its constitutive components (Holling, 1973; Holling 1978). Beyond given thresholds, SESs shift into a different regimen involving structural modifications (Holling, 1978; Walker et al. 2006; Janssen et al. 2007); these regimens are termed “alternative regimen". In the Senegal River delta and estuary, the whole system has undergone just such a regimen shift (Scheffer et al. 2001; Carpenter 2003; Walker et al. 2006), that seems irreversible in the medium term. The alternative regimens may be of benefit to some stakeholders; however, they have unwanted or mixed effects for others. Within the emerging alternative systems, the unwanted effects, e.g., Typha australis proliferation, increasing salinity of the water, and water tables located near the river, or increased tidal range in the estuary, are of greatest concern as they are often resilient.

The hydraulic infra-structure adjustments were achieved under the pretext of more efficient use of water resources and enhanced control over uncertainties (Gunderson 1999; Gunderson and Holling 2002; Walker et al. 2003; Pahl-Wostl et al. 2007). Uncertainty can be defined as events that are not fixed or determined, and by extension, as worries about an unknown future. Often associated with anxiety, uncertainty has always been an inherent factor in the lives of those who 
live in the Sahel region, due to rainfall variability affecting crop-growing and pastoral resources. Such uncertainty depends on different parameters (e.g., the date at which effective rain begins to fall, the occurrence, duration and intensity of dry periods during the rainy season, etc.), and is part of a definite, seasonal timeframe. Uncertainty is thus perceived as normal, expected, and understood within these communities. As such, over time it has shaped the adaptive strategies of the SESs, enabling them to attenuate the climatic risks. Also expected, but less well understood, is the uncertainty experienced by those who rely on the river for their water supply, when the latter is dependent on climatic conditions higher up in the catchments. Furthermore, the climatic uncertainty may involve greater or lesser constraints. For instance, a severe drought lasting several years is difficult to endure and may no longer seem acceptable to the stakeholders today, as technological solutions may be available. Societies depending on technology are therefore tempted to solve such recurrent problems with solutions such as dams. This was the case in the Senegal River basin with the building of the Diama and Manantali dams, in 1985 and 1988 respectively, after 20 long years of drought (see Fig. 1).

New environmental disturbances are however emerging, for which no measures of compensation or attenuation had been planned, financially or otherwise. Thus, the nature of uncertainties has changed and humans no longer seem to be able to manage them, although they will eventually adjust in the course of time. Many of the uncertainties discussed below stem from flaws found in the impact studies (Gannett, Fleming, Corddry, and Carpenter Inc. 1978, 1980; Euroconsult and Sir Alexander Gibb Inc., 1990), which either did not document the difficulties likely to arise after such radical landscape transformation (Engelhard 1991; Kane, 1997; Blanchon 2003; Leroy 2006), or whose purpose was not to devise compensatory measures. Although the benefits derived from a dam can only be assessed in the long term, the period of adaptation and uncertainty is a difficult one for local inhabitants, and needs to be anticipated, and attended to, to as great a degree as possible.

\section{Methods and History of the Case Study}

The first approach is an assessment of the consequences of area planning, based on a comparison between the initial objectives and the present situation. The second approach aims to describe the impacts of the development, especially those impacts that went unmentioned or were not 
anticipated during initial planning stages. Incomplete objectives and unexpected impacts lead to disappointment and require rectification, at best, or compensation. Compensatory measures, however, are always undertaken in retrospect and are often designed as a response to a crisis or implemented by trial and error, and in themselves can create unforeseen problems. Both our approaches involved a qualitative and quantitative assessment of the current situation. Specifically, we made field observations and interviews,as well as on-site measurements (topometry, water salinity, and piezometry for the level of the water tables). Our fieldwork was supplemented by an analysis of existing data from the hydroclimatic database (Institut de Recherche pour le Développement, 2008).

During the 1970s and 1980s, the whole of West Africa was affected by drought, as shown by the graphs of ten-year mean isohyets (equal rainfalls contour lines, (Puech 1983; Albergel et al. 1984; Venema et al. 1997); with the $800 \mathrm{~mm}$ isohyet moving southwards by nearly two degrees of latitude along certain meridians. In the Sudanese Sahel, the flow of the Senegal River was reduced significantly; at Bakel the annual mean flow dropped by an average of $75 \%$ between 1970 and 1990, and by 50\% during the 1980s (Mahé and Olivry 1995). Because of growing official concern and increasing international awareness, the OMVS, a tripartite authority (Mali, Mauritania, Senegal), was established in March 1972, with the major objective of improving the three member countries' food supply by creating 375,000 ha (hectares) of irrigated land for rice cultivation: 240,000 ha in Senegal, 126,000 ha in Mauritania and 9,000 ha in Mali. The annual yield of the hydro-agricultural schemes was forecast to be 12 tons per hectare, in addition to a farming-sector growth rate of $10 \%$ per annum (Leroy 2006). Two dams were built to achieve these aims (see Fig. 1): Diama for preventing intrusion of sea water upstream, Manantali for supplying irrigated farmland with water and the three countries' fast-growing capitals with electricity. The dam's hydroelectric power station has a generating capacity of $800 \mathrm{GwH}$ a year. Finally, because releases of water from Manantali dam were expected to keep the river's water level high enough during the dry season, year-round boat traffic, running from Saint-Louis to Kayes in Mali was been planned. Two decades later, the outcomes of three important domains: navigation, irrigation and hydroelectric power production, can be assessed.

Regarding navigation, as could be expected, there has been no improvement in the Senegal River's navigability to Kayes in Mali. Large financial investments would have been necessary to 
upgrade the riverbed morphology, and this was unlikely because trade between Mali and the ocean does not transit through Saint-Louis, the city having no proper port facilities.

Irrigated agriculture, presently covering 125,000 ha of large plots, is developing much slower than initially planned. Only one-third of the areas equipped for irrigation are currently cultivated (Bader et al. 2003). On individual plots, crop yields rapidly dropped to an average of four tons per hectare after three years of cultivation (Ceuppens and Woperei 1999). This poor outcome is due to several factors, in particular hydraulic (de Montgolfier 1996). Specifically, crop- growing soils remain fragile due to salinisation. Protection against salinity requires a well-designed drainage network. In practice, the area's drainage is often badly designed, poorly maintained, or simply non-existent, resulting in increasing salinity of areas that eventually have to be abandoned. In addition, waste water carrying pesticides and weed-killers are not properly disposed of (Mietton et al. 1991; Humbert et al. 1995). Although a canal to evacuate waste water was planned in the impact studies (UNEP/UCC-WATER/SGPRE 2002), it was never budgeted for and, as of November 2008 remains incomplete. Drainage techniques are poor, and it is difficult to get rice fields perfectly level (Pesneaud 1996; Leroy 2006). Finally, the fields are too large for the insufficiently mechanized farming techniques in use.

The objectives for hydroelectric power production were met by 2002 . The three national capitals now have reliable power supplies, and both living conditions and production environment have greatly improved. Power production, however, is now subjected to new constraints. The Manantali's water reserve is not only used to generate hydroelectric power, but also to compensate for inadequate flooding of fields or low river flow, and also allows for some postflood as well as irrigated crop-growing (Bader et al. 2003). The advantages and potentials of flood regression agriculture (Acreman et al. 2000; Acreman 2001), whose yields are low (about 1 ton/ha/year), had clearly been under-estimated. Although expected to be only temporary, this practice has turned out to be essential for the communities of the lower-middle valley. Eventually, the objectives assigned to the Manantali dam may end in a conflicting situation in the course of time, due to the competing needs of water storage for electricity production and water releases for flood regression agriculture (Acreman et al. 2000; Acreman 2001). 
Thus, because of contradictory objectives and rapid, imperfect adaptations, the era of uncertainty is not yet over for the local communities. Nevertheless, on the Mauritanian side of the river at least, improving water management skills have begun to bear fruit, with uptrend in biodiversity and economic production (Duvail 2001; Duvail et al. 2001). Unfortunately, the artificial breaching of the Barbary Spit in late 2003 compounded the situation. The level of the Senegal River at Diama had steadily risen throughout September 2003 leading to the flooding of SaintLouis. The flood alert threshold of $1.20 \mathrm{~m}$ (UNEP/UCC-WATER/SGPRE 2002) was observed by mid-September. A maximum height of $1.42 \mathrm{~m}$ above the reference level was reached on September 28th, and remained at $1.41 \mathrm{~m}$ over the following days. Given the flows recorded upstream at Bakel, the river was forecast to keep rising significantly over the following days. Indeed, a maximum flow rate of $3505 \mathrm{~m} 3 / \mathrm{s}$ was recorded at Bakel (see Fig. 1) on the 23rd of September. The rise of the water level clearly demonstrated that the drainage basin, downriver from Bakel, was not regulated by the Manantali Dam; the inflows from the Falémé and Baoulé rivers, as well as the severe Sahelian floods (Térékollé, Kolimbiné, Lake Magui) were not controlled. In addition, because of the hydroelectrical management of the dam since the end of 2002, the Manantali reservoir was full and could no longer limit potential floods caused by storms at the end of the rainy season. Downriver, Diama suffered from uncontrolled flooding, which can take approximately 20 days to arrive from Bakel. Faced with concerns expressed by the Saint-Louis inhabitants and perhaps under pressure from the authorities, the basin managers decided to open a breach across the narrow coastal spit, to bring about a reduction in the slope of water surface. It should be noted that this flood-protection measure had been mentioned in an earlier UNEP/UCC-WATER/SGPRE report in October 2002, in conjunction with additional measures, such as the construction of protective breakwaters, next to the breach. During the night of October 3rd, a 4 m-wide channel was dug (see Fig. 2); the height of the river, as measured at the Faidherbe Bridge, dropped dramatically over the following 48 hours and by approximately a meter in 10 days. However, the breach widened rapidly (Kane et al. 2003), reaching $400 \mathrm{~m}$ in a few weeks, and continued opening at a steady rate of about a meter a day. In April 2006, the breach was $1.4 \mathrm{~km}$ wide. (see Fig. 2). Since then, the opening seems to have remained stable. 


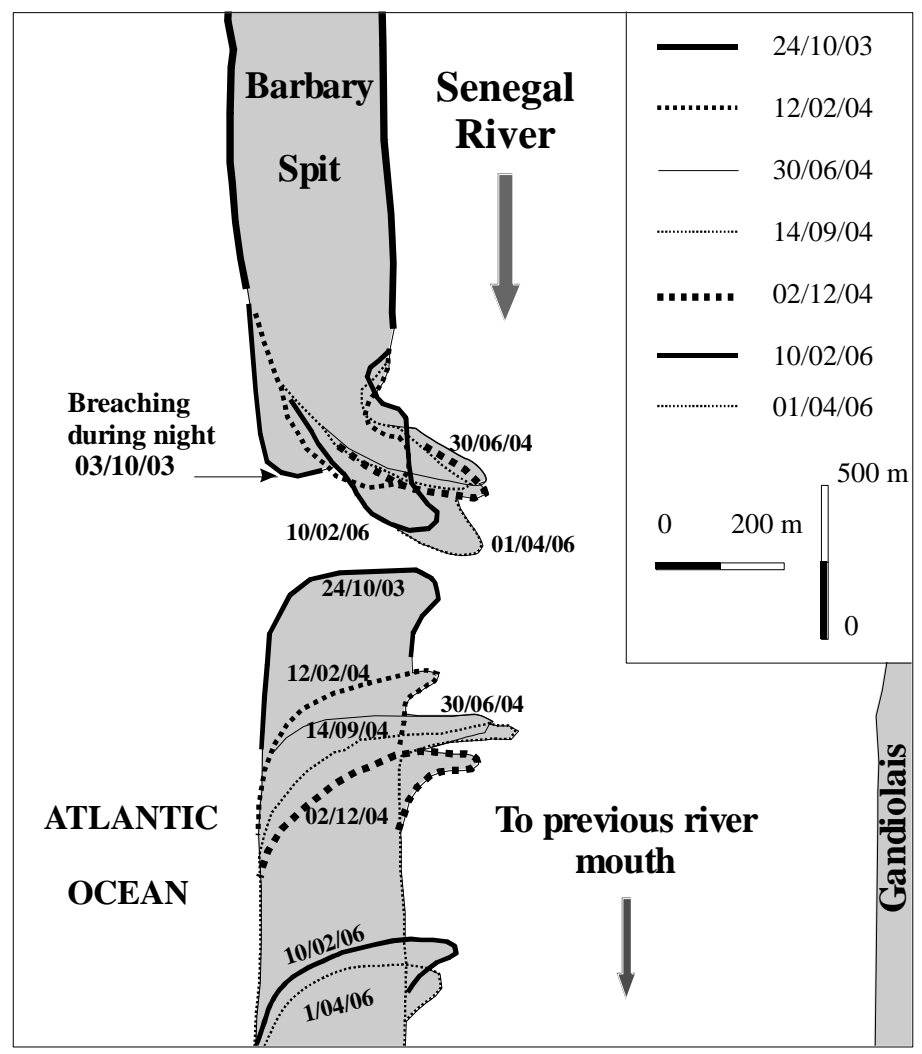

Fig. 2. Time-space evolution of the new river mouth between October 2003 and April 2006 (data from N. Guiguen and co-authors)

\section{Key findings}

The building of the hydraulic structures (the dams, free-flow canals, embankments, sluicegates and irrigation ditches) in the valley since the 1980s and, more recently, the artificial breaching of Barbary Spit in 2003, have contributed to the emergence of new, ecological and socio-economic difficulties. These difficulties are complex and often integrated. The major impacts, and those with the most durable consequences, probably occur in the socio-economic domain, as for example the out-migration of communities from the Gandiolais' area (see Fig. 1). However, the impacts caused by the hydraulic development differ in both form and time between the estuary and the middle delta, upriver from Diama. Like all dams, Diama has created a boundary. Being an anti-salt barrier, Diama divides the upriver and downriver areas into two highly distinct 
hydrographical sectors with regards to water quality (Barusseau et al. 1998). Within the estuary, it is still too early for a proper assessment of the impact of the artificial opening of Barbary Spit to be undertaken. The remedy chosen to deal with flood risks at Saint-Louis may nevertheless prove to be worse than the original affliction, at least in the section downriver from Diama, where the water table salinity has much increased.

\section{The Middle Delta}

Originally designed as a barrier against salt intrusion, the Diama dam has gradually been assigned an extra function as a reservoir: the average water level of $1.50 \mathrm{~m}$ in 1992 rose to 1.75 $\mathrm{m}$ in $1995,1.90 \mathrm{~m}$ in $1997,2.0 \mathrm{~m}$ in 1999 and has been $2.10 \mathrm{~m}$ since 2002 . This is an instance where hydraulic engineers are being asked to respond to the persistent farming and agroindustrial demands by maintaining high water levels to ensure gravitational irrigation of the farmland (Duvail 2001).

The changes in the hydrological factors (reduction in salt water intrusion, stability of water levels and increased irrigation potential) appear to have contributed to the emergence of new health problems such as bilharziosis and malaria. For instance, Handschumacher (Philippe et al. 1998) explains how the epidemic of intestinal bilharziosis in the town of Richard Toll (Senegal, see Fig. 1), found outside of the usual distribution of Schistosoma mansoni in West Africa, was able to gain hold in a new ecological environment. This was due to the existence of permanent fresh water, the regulation of the levels of Lake Guiers, and the presence of water canals supplying the nearby sugarcane fields. This link, however, has not been proven, and must be considered with caution. "The relationship between the presence of intermediate hosts or vectors and a specific disease (e.g, bilharziosis, malaria) is neither immediate nor inevitable. In the same way, there is no obvious link between irrigated areas and the appearance of intermediate hosts and vectors," (Philippe et al. 1998, p. 398). Indeed, the transmission cycle of the vector can only be completed by infestation of intermediate hosts, and this can only occur through diseased people arriving from a zone where the disease is endemic. Richard Toll is a plantation town that has attracted a large labor force, some of it arriving from the south of the country where bilharziosis is endemic. The Diama anti-salt dam cannot, therefore, be implicated in the spread of the disease. The 
influence is an indirect one, as the increased availability of water for irrigation has favored the extension of sugar-producing areas and the expansion of the work force.

A major difficulty stressed by all stakeholders has been the increase in the number of invader aquatic species, linked to the permanent presence of fresh water upriver from Diama. Although the proliferation of plants such as Salvinia molesta and Pistia stratiotes are now under control based on our field observations; others such as Typha australis are becoming an increasing concern. Biological methods of control are not yet effective, while removal by mechanical means requires considerable physical and financial efforts and only yields a short-term benefit. This type of infestation has seriously impaired access to, and movement around, waterways, especially for fishermen. Canal and tributary flow has become sluggish and sedimentation is increasing (Philippe et al. 1998). This has resulted in sheltering and nesting possibilities for animal species, such as the grain-eating bird Quelea quelea, which feeds on cultivated land.

The North bank of the river is characterized by a mosaic of landscapes in which rice plots do not yet occupy the whole space and traditional activities such as fishing, livestock breeding, and gathering still persist near the protected ecosystems of the Diawling Park (PND), a protected area created and supported by the International Union for Conservation of Nature (IUCN). It has now become feasible to generate floods during the dry season through the sluicegates located on the north bank embankment. However, this artificial flooding is likely to give rise to conflicts between local stakeholders (fishermen, stock-breeders, etc.). This is why a time frame had been agreed upon between these groups and park managers regarding the flooding of the basins during the dry season (Duvail et al. 2001; Duvail and Hamerlynck 2003; Hamerlynck et al. 2005). Yet, between 2002 and 2006, the basins were dried out in spite of the agreement in order to limit Typha propagation. Everybody was satisfied - except the stockbreeders who need a short counter season flood after the dry season for their herds (camels, bovines, sheep, goats). It is likely that the lack of respect or adherence to the implemented management plan will provoke a long lasting discontentment on the part of stockbreeders.

The economic and financial feasibility of developing a new industry to promote the use of Typha australis (for fuel, methane production, wickerwork, building material, and animal fodder) 
became moot. In addition to creating a large number of jobs, it would most likely be the best way to control the spread of Typha (Theuerkorn and Henning 2005).

\section{The Estuary}

In October 2003, when the city of Saint-Louis was flooded, an artificial canal was dug across Barbary Spit, as explained above. This had positive effects as the flood of Saint-Louis receded immediately. However, the artificial breach has also had negative effects, such as a massive penetration of sea water into the lower estuary and a greater daily fluctuation in water levels.

With respect to the beneficial effects, in the two years following the digging of the breach, the water level at Saint-Louis has not exceeded $50 \mathrm{~cm}$, although the outflow volumes from the Diama dam did not change compared to the previous years. The radical change in the slope of the water line (a more than twofold increase) suggests that Saint-Louis flood risk has been alleviated. Nevertheless, to improve safety and reduce the amount of water released during the high water level period, the coordinated management of the two dams, however complex it may be in the Manantali-Diama stretch, should take into account the downriver section between Diama and the new river mouth.

The opening of the breach has also led to two negative effects: an increase in the tidal range and an increase in the salinity level throughout the estuary. The increase in tidal range has been the most obvious and the least questionable effect of the changes to the mouth of the river. Modifications in semi-diurnal tide patterns can be seen in a number of ways (). Firstly, the daily maximum tidal range, as measured downriver from Diama, has increased by a factor of three, from a 2001-2002 average of $0.30 \mathrm{~m}$ to an average of $0.93 \mathrm{~m}$ in 2004-2005. Furthermore, since 2004, the tidal range can be seen year-round, including during the rainy season, which was not previously the case. Finally, the amplitude of the 14-day spring-tide cycle has been reinforced. At Diama, the amplitude between spring-tide and its accompanying neap-tide has more than doubled. From a geotechnical standpoint, such a tidal range can have undermining and/or gouging effects on the wharves of Saint-Louis, the piers of Faidherbe Bridge, and the foundations of the Diama Dam. It was in this context that a new study of the dissipation energy downriver from Diama was ordered by the dam managers. Management of the Diama Dam should take into account both the dam's own mechanical stability and its new function as a 
reservoir, which had not originally been planned. With regard to the first point, until recently, dissipation energy had been strictly limited to $1000 \mathrm{~m} 4$ /s (for instance, $1000 \mathrm{~m} 3$ /s under a onemeter drop between upstream and downstream : $1000 \mathrm{~m}^{3} / \mathrm{s} \times 1 \mathrm{~m}=1000 \mathrm{~m}^{4} / \mathrm{s}$ ) by the regulations governing the management of the dam (Coyne and Bellier Inc. and SOGREAH Inc. 1987). Today, the increase in tidal range has led to a water fall which exceeds one $\mathrm{m}$, and has therefore forced the Diama Dam's managers to restrict the volume of water released. However, a recent engineering study (J.-P. Lamagat, director of research IRD, and N. Guiguen, engineer IRD, February 2006, pers. Comm.) and new computations state that the dissipation energy could reach $15,000 \mathrm{~m} 4 / \mathrm{s}$ without threatening the dam's stability. This fifteen-fold increase may come as a surprise, particularly when one remembers the worries regarding the dam that were expressed in 2004 and 2005.

The salinity level appears to be increasing in the estuary under the influence of two opposing factors: a more hydrodynamically-efficient intrusion of sea water up to Diama; and, since late 2002, the discharging of fresh water at Diama. The latter has never dropped below 100 - 200 $\mathrm{m} 3 / \mathrm{s}$ and is equivalent to the amount forced through the turbines at Manantali during the dry season. The situation has changed from that of the late 1980s and 1990s. At that time, the dam would be closed for extended periods resulting in an excessive buildup of salt in the estuary (for instance, salt content reached $35.9 \mathrm{~g} / \mathrm{l}$ at Saint-Louis in May 1992, a level similar to sea water salinity (Cecchi 1992)) and in the noticeable retreat of mangrove ecosystems. Although surface salinity varies over space and time, it did not exceed 20 g/l, in December 2004, May 2005 and February 2006, despite low discharge rates from Diama. However, the downriver section of the river, between the new and old mouth, is now filled in. This section is near the ocean and is turning into a lagoon and will most likely have a very high salt content due to the lack of a "flushing" effect. The flow of seawater into this area might be a threat to cropping, forestry and pastoral activities and to fresh-water supplies needed for the market-gardening economy of the Gandiolais district (Diallo 2005). The thin layer of fresh water overlying the saltwater table in the lower delta's sand-dune area had enabled the Gandiolais, downriver from Saint-Louis, to become an economically dynamic zone. The freshwater table had started to fall in the 1970s, due to drought, then due to development works on the river, and finally to the disappearance of natural flooding. This drop in the water supply encouraged the planting of onions, a new crop requiring less water, in place of other traditional vegetables (Bonnardel 1992). This thin layer of 
fresh water is threatened since the Barbary Spit breach was opened. The resulting amplification of the tidal range and salt water intrusion has led to an increased contamination of the water table. Salinity can reach $2.9 \mathrm{~g} / \mathrm{l}$ on plots located near the river, a level considered too high for crop production; consequently plots closer to the river have been abandoned in the last year or two, with well water having a salt content of $12.5 \mathrm{~g} / \mathrm{l}$.

\section{Discussion and Conclusions}

The transformation of the Senegal River Valley, planned in the 1970s and carried out in the late 1980s, implicitly presupposed the successful change from a seasonal economy of hunting and gathering and extensive agriculture to one consisting of intensive, permanent agriculture, whose profitability was overestimated from the outset (Engelhard 1991; Duvail 2001).Initial objectives for crop yields and irrigated areas have fallen short. Extensive restoration works in the transformed areas are necessary in the short term, and will prove costly for farmers' organizations. Indeed, since the withdrawal of the National Society for the Development and Operation of the Senegal River, (SAED, Société nationale d'Aménagement et d'Exploitation du Delta et de la vallée du fleuve Sénégal) in 1987, the cost of restoration work is incumbent upon the farmers (Boutillier, 1989; Leroy 2006); financial assistance is not available. A final restoration was performed by SAED before turning the land over to the farmers' organization. Since then, farmers can only level the land every three to five years because of the high cost of the mechanized operation (Boutillier 1989).

Rice growing has turned out to have high social and ecological costs. The decision to create ex nihilo a rice growing sector dependent on irrigation was a political and macroeconomic decision. It was reinforced by the possibility of developing the hitherto sparsely populated area into a fertile wetland through the supply of gravity-fed irrigation water at a very low cost. Currently, the situation is economically, environmentally, and institutionally deadlocked. Confronted with so many obstacles and setbacks, the future of the chosen approach seems open to question (Pesneaud 1996). Over the past two decades, stakeholders have had to adapt, first to the delayed building of an embankment along the north bank, and then to frequent, unpredictable, modifications in the management of the Diama and Manantali Dams. This raises the question of 
whether a more detailed impact assessment should be carried out prior to the construction of such large dams.

With respect to the lower river course, the hydraulic infrastructure and dam management have had mixed effects on the flooding of the city of Saint-Louis. Flood intensity is not only related to the maximum height reached by the river, but also to the duration of the flood, local rainfall and effectiveness of embankments. The 2003 flood, although a major one, was not exceptional: the maximum water level recorded at Saint-Louis was $142 \mathrm{~cm}$, much lower than in 1999 (164.5 cm) or $1950(179 \mathrm{~cm})$ (Laperrière and Luchetta 2003). The intensity of the 2003 flood is likely to have been aggravated by the impediment of the flow downriver due to the partial blocking of the old river mouth, which had been dredged regularly up to the 1960s. It can nevertheless be hypothesized that it is not so much the hydrological conditions that have changed, as SaintLouis's own self -induced vulnerability due to the expansion of housing developments, particularly in the low-lying part of the town. This may be due to several factors: overconfidence during flood-free years aggravated by poor urban planning; widespread excessive cost of land; lack of space for new housing areas forcing marginalized people to set in inappropriate sites; as well as limited urban planning. The building of the dams may have led to the belief that there was no longer any danger of flooding. In the future, to limit flood risks in the city, the joint management of the two dams should take into account safety concerns downstream from Diama. It appears necessary to start drawing up a new management model for the dams, taking into consideration both the concerns of the city of Saint-Louis and the morphological evolution of the new river mouth.

In today's Senegal River Delta, environmental uncertainty is being experienced in a number of ways: ecological, socio-economic, and sanitary. The common concern is the uncertain control of the quantity and quality of water resources (fresh, brackish, and sometimes waste water). The monitoring of ecological parameters and socioeconomic indicators is urgently required, as is the hydraulic modeling of the section of the river between Diama and the ocean. Hydraulic modeling should be carried out in conjunction with a digital landscape model of the flood plain, something that does not yet exist. 
To conclude, we would stress the need for a more efficient management model that would encompass the two dams and integrate the Diama-Ocean stretch. This hydraulic model should consider a way to regulate extreme flows by ensuring a minimum flow for alleviating the oversalinisation risk in the estuary on the one hand, and a maximum flow level that should not be exceeded for Saint-Louis flood security on the other. Moreover, this complex model must take into account the known variations of tidal ranges. This integration of both quantitative and qualitative aspects of the river's characteristics would enable one to develop a cohesive, comprehensive, and 'workable' approach. A participatory process, to be initiated by city planners and dam managers, is likely to achieve this aim and help reducing uncertainties linked to large dam projects.

\section{Acknowledgements}

This project was supported by the MIRA program of the Région Rhône-Alpes (France). The authors would like to thank the IRD (French Research and Development Institute) in Dakar, and particularly N. Guiguen for making hydrometric data available; the staff of the OMVS, especially at Diama; the Direction de l'Hydraulique headquarters in Saint-Louis and the anonymous reviewers for their helpful comments on earlier drafts of this article.

\section{References}

Acreman, M.C., Farquharson, F.A.K., McCartney, M.P. Sullivan, C., Campbell, K., Hodgson, N., Morton, J., Smith, D., Birley, M., Knott, D., Lazenby, J., Wingfield \& Barbier, E.B. 2000. Managed flood releases from reservoirs: issues and guidance. Report to DFID and the World Commission on Dams. Centre for Ecology and Hydrology: Wallingford, UK.

Acreman, M.C. 2001. World Bank water resources and environmental management, Best practice brief no 8. Environmental flow assessment, Part III: case studies of managed flood releases. World Bank: Washington, DC. 
Albergel, J., J.-C. Bader, J.-P. Lamagat, and L. Séguis. 1984. Crues et sécheresses sur un grand fleuve tropical de 1'Ouest africain: application à la gestion de la crue du fleuve Sénégal. Sécheresse 3(4): 143-152.

Anderies, J.M., M.A Janssen, and E. Ostrom. 2004. A framework to analyze the robustness of social-ecological systems from an institutional perspective. Ecology and Society 9(1): 18.

Bader, J.C., J.P. Lamagat, and N. Guiguen. 2003. Gestion du barrage de Manantali sur le fleuve Sénégal : analyse quantitative d'un conflit d'objectifs. Hydrological Sciences Journal 48(4): 525-538.

Barusseau, J.P., M.B. Cyr Descamps, E. Salif Diop, B. Diouf, A. Kane, J.-L. Saos, and A. Soumaré. 1998. Morphological and sedimentological changes in the Senegal River estuary after the constuction of the Diama dam. Journal of African Earth Sciences 26 (2): 317-326.

Belloncle, G. 1985. Participation paysanne et aménagements hydro-agricoles. Paris: Karthala, Collection Economie et Développement.

Berkes, F., J. Colding, and C. Folke. 2003. Navigating social-ecological systems: Building resilience for complexity and change. Cambridge, UK: University of Cambridge Press.

Blanchon, D. 2003. Impacts environnementaux et enjeux territoriaux des transferts d'eau inter bassins en Afrique du Sud. PhD dissertation, Université de Paris X Nanterre, France.

Bonnardel, R. 1992. Saint-Louis du Sénégal: mort ou renaissance ? Paris: L’Harmattan.

Boutillier, J. L., and J. Schmitz. 1987. Gestion traditionnelle des terres (système de décrue / système pluvial) et transition vers l'irrigation : Cas de la vallée du Sénégal. Cahiers des Sciences Humaines 23(3-4): 533-554.

Boutillier, J. L. 1989. Irrigation et problématique foncière dans la vallée du Sénégal. Cahiers des Sciences Humaines 25(4): 469-488. 
Carpenter, S. R. 2003. Regime shifts in lake ecosystems. Ecology Institute, Oldendorf/Luhe, Germany.

Cecchi, P. 1992. Phytoplancton et conditions de milieu dans l'estuaire du fleuve Sénégal : Effets du barrage de Diama. PhD dissertation, Université de Montpellier II, Travaux et Documents de l'ORSTOM Microédités n94, Paris, France.

Ceuppens, J., and M.C.S. Woperei. 1999. Impact of non-drained irrigated rice cropping on soil salinization in the Senegal River Delta. Geoderma 92 (1-2): 125-140.

Coyne and Bellier Inc., and Société Grenobloise d'Etudes et d'Applications Hydrauliques (SOGREAH) Inc. 1987. Consignes générales d'exploitation et d'entretien du barrage de Diama. OMVS, Grenoble, France.

De Montgolfier, J. 1996. Interrogations sur le développement durable dans le delta du fleuve Sénégal. Compte-rendu de mission janvier 1996. In Transformations des hydrosystèmes en aval des grands barrages. Programme CNRS - PIR EVS SEAH, M. Mietton (ed.), Pp. 321. Strasbourg, France.

Diallo, M. 2005. Etude de la baisse du niveau de la nappe dans les Niayes du Gandiolais. Master's thesis. Université Gaston Berger, U.F.R. Lettres et Sciences Humaines, section Géographie, Saint-Louis, Senegal.

Duvail, S. 2001. Scénarios hydrologiques et modèles de développement en aval d'un grand barrage. Les usages de l'eau et le partage des ressources dans le delta mauritanien du fleuve Sénégal. PhD dissertation. Université Louis Pasteur Strasbourg I, U.F.R. de Géographie, Strasbourg, France.

Duvail, S., and O. Hamerlynck. 2003. Mitigation of negative ecological and socio-economic impacts of the Diama dam on the Senegal River Delta wetland (Mauritania), using a model based decision support system. Hydrology and Earth System Sciences 7 (1): 133-146. 
Duvail, S., M. Mietton, and P. Gourbesville. 2001. Gestion de l'eau et interactions sociéténature. Le cas du delta du Sénégal en rive mauritanienne. Nature Sciences Sociétés 9(2): 516.

Engelhard, P. 1991. La vallée "revisitée" ou les "Enjeux de l'après-barrage" cinq ans plus tard. In $\mathrm{La}$ vallée du fleuve Sénégal. Evaluations et perspectives d'une décennie d'aménagements, B. Crousse, P. Mathieu and S. M. Seck (eds.) Pp. 45-79. Paris: Karthala.

Euroconsult, Sir Alexander Gibb and Partners. 1990. Plan Directeur intégré pour la rive gauche de la vallée du fleuve Sénégal. Ministère du Plan et de la Coopération de la République du Sénégal, Dakar, Sénégal/PNUD/BIRD.

Gannett, Fleming, Corddry, and Carpenter Inc. 1978. Evaluation des effets sur l'environnement d'aménagements prévus dans le bassin du Fleuve Sénégal. 20 vol., OMVS, Dakar, Sénégal.

Gannett Fleming Corddry and Carpenter Inc. 1980. Assessment of environmental effects of proposed developments in the Senegal River Basin. OMVS, Dakar, Sénégal.

Gunderson, L., 1999. Resilience, flexibility and adaptive management-antidotes for spurious certitude. Conservation Ecology 3(1): 7.

Gunderson, L.H., and C.S. Holling (eds.). 2002. Panarchy: Understanding transformation in human and natural systems. Washington, D.C.: Island Press.

Hamerlynck, O., S. Duvail, B. Messaoud, and M. Benmergui. 2005. The restoration of the Lower Delta of the Senegal River, Mauritania (1993-2004). Presented at: Symposium on Coastal Ecosytems of West Africa, Brussels, Belgium. 15-16 February.

Holling, C.S. 1973. Resilience and stability of ecological systems. Annual Review of Ecological Systems 4: 1-23.

Holling, C.S., editor, 1978. Adaptive environmental assessment and management. New York: John Wiley. 
Humbert, J., M. Mietton, and A. Kane. 1995. L'après-barrages dans le delta du Sénégal. Scénarios de remise en eau de la cuvette du N'Diael et impacts. Sécheresse 6(2): 207-214.

Institut de Recherche pour le Développement (Research and Development Institute). 2008. Hydroclimatic database, Hydraccess, OMVS-SOE.

Janssen, M.A., J.M. Anderies, and E. Ostrom. 2007. Robustness of social-ecological systems to spatial and temporal variability. Society and Natural Resources 20: 307-322.

Kane, A. 1997. L'après-barrages dans la vallée du fleuve Sénégal: modifications hydrologiques, morphologiques, géochimiques, sédimentologiques. Conséquences sur le milieu et les aménagements hydro-agricoles. PhD dissertation. Dakar, Senegal : Université Cheik Anta Diop.

Kane, A., I. Niang Diop, A. Niang, and A.M. Dia. 2003. Coastal impacts of water abstraction and impoundment in Africa. Cas du bassin du fleuve Sénégal. Report. LOICZ/START AfriCat Foundation Project, Université Cheik Anta Diop, Dakar, Sénégal.

Laperrière, V., and J. Luchetta. 2003. La dynamique du risque d'inondation à Saint-Louis au Sénégal. Master's thesis. Université Joseph-Fourier, Institut de Géographie Alpine: Grenoble, France.

Leroy, M. 2006. Gestion stratégique des écosystèmes du fleuve Sénégal. Actions et inactions publiques internationales. Paris: L'Harmattan, Etudes africaines.

Mahé, G., and J.C., Olivry. 1995. Variations des précipitations et des écoulements en Afrique de l'Ouest et central de 1951 à 1989. Sécheresse 6(1): 109-117.

Michel P., 1973. Les bassins du fleuve Sénégal et Gambie: étude géomorphologique. PhD dissertation. University of Strasbourg : Strasbourg. France.

Mietton, M., J. Humbert, and S. Richou. 1991. Le projet de remise en eau du N'Diael (Sénégal). Pré-faisabilité hydraulique, bilan hydrologique et impacts. Consultants' report for the C.I.C. Université Louis Pasteur Strasbourg. CEREG URA 95, Strasbourg, France. 
Pahl-Wostl, C., J. Sendzimir, P. Jeffrey, J. Aerts, G. Berkamp, and K. Cross. 2007. Managing change toward adaptive water management through social learning. Ecology and Society 12(2): 30 .

Pesneaud, F. 1996. Artificialisation du milieu, introduction de techniques nouvelles et recomposition sociale: à propos de la riziculture du delta du Sénégal. Compte-rendu de mission janvier 1996. In Transformations des hydrosystèmes en aval des grands barrages. Programme CNRS - PIR EVS SEAH. M. Mietton (ed.). Pp. 22-41. Université Louis Pasteur Strasbourg. CEREG URA 95, Strasbourg, France.

Philippe, C., A. Kane, P. Handschumacher, and M. Mietton. 1998. Aménagements hydrauliques et gestion de l'environnement dans le delta du fleuve Sénégal. In Pratiques de gestion de l'environnement dans les pays tropicaux: Dymset, CRET, Espaces tropicaux $\mathrm{n}^{\circ} 15$, Bordeaux, France, Pp. 389-401.

Puech, C. 1983. Persistance de la sécheresse au Sahel. Conséquences sur les normes hydrologiques et pluviométriques. Ouagadougou, Burkina Faso: C.I.E.H. série Hydrologie.

Scheffer, M., S.R. Carpenter, J.A. Foley, C. Folke, and B. Walker. 2001. Catastrophic shifts in ecosystems. Nature 413: 591-596.

Theuerkorn, W., and R.K. Henning. 2005. Energies renouvelables: Typha australis, menace ou richesse? Comité permanent Inter-Etats de Lutte contre la Sécheresse dans le Sahel, Bundesministerium für wirtschaftliche. Zusammenarbeit und Entwiclung. PREDAS, Ouagadougou, Burkina Faso.

UNEP/UCC-WATER/SGPRE. 2002. Towards an integrated management of the coastal zone and the Senegal river basin. Pilot program for the left bank of the Senegal river delta and its coastal zone, Dakar, Senegal.

Venema, H.D., E. J. Schiller, K. Adamowski, and J.-M. Thizy. 1997. A Water Resources Planning Response to Climate Change in the Senegal River Basin. Journal of Environmental Management 49(1): 125-155. 
Walker, B., L. Gunderson, A. Kinzig, C. Folke, S. Carpenter, and L. Schultz. 2006. A handful of heuristics and some propositions for understanding resilience in social-ecological systems. Ecology and Society 11(1): 13.

Walker, W., P. Harremoës, J. Rotmans, J. Vander Sluijs, M. Van Asselt, P. Jansen, and M.P. Krayer von Krauss. 2003. Defining uncertainty: a conceptual basis for uncertainty management in model-based decision support. Journal of Integrated Assessment 4(1) : 517. 